\title{
SUBLIME LOVE AND THE ETHICS OF EQUALITY IN A HOMOEROTIG NOVEL OF THE NINETEENTH CENTURY: PRECIOUS MIRROR OF BOY ACTRESSES
}

\author{
BY
}

\author{
KEITH McMAHON
}

(University of Kansas)

\begin{abstract}
Precious Mirror of Boy Actresses is the most serious piece of fiction about male love since the late Ming and the lengthiest of all in Chinese literary history. It is remarkable in its extension of the egalitarian implications of the qing aesthetic that it inherits from the late Ming and from earlier Qing literature such as Dream of the Red Chamber. In the homoerotic relationship it idealizes, lovers who are rigidly separated in terms of status nevertheless experience a sublime love which necessarily results in the liberation of the man of lower status. The novel makes unique use of the qing aesthetic's idealization of the feminine to arrive at this ethically pragmatic conclusion whereby liberation is achieved. The foregrounding of this sublime love and the qing-perfected characters who embody it, moreover, link the novel with other works of the period which portray a China that is ultimately a stable and invulnerable entity. Thus Precious Mirror's interpretation of qing carries a historical significance in spite of the novel's obliviousness of the social and political turmoil of China in the mid-nineteenth century.
\end{abstract}

\section{Part I The Literary and Social Context}

The Boy Actress and the Young Scholar

The mid-nineteenth century novel Pinhua baojian 品花寶鑑(Precious mirror of boy actresses), by Chen Sen 陳森 (ca. 1796-1870), is the lengthiest fictional work about male love since the late Ming anthologies Bian er chai 弁而釷 (Cap and hairpins) and Fichun xiangzhi 宜春香質 (Fragrant essences of spring)..$^{1}$ It emerges from an urban

1 The text I use is Chen Sen, Pinhua baojian (Taibei: Guiguan tushu gufen youxian gongsi, 1986), which I will cite by chapter number followed by page number. Other late Ming or early Qing works centering on male homoeroticism include Longyang yishi 龍陽婏史 and stories in Shi dian tou 任點頭 (fourteenth story), Li Yu's 李漁 Wusheng xi 無聲战 (sixth story), and other collections as well as Wang Jide's 王䮙

(C) Brill, Leiden, 2002

NAN NÜ 4.1 
milieu of acting and actors in which male homoeroticism was a prominent facet. ${ }^{2}$ Its attraction for us starts with the fact that, along with other major novels of the turbulent mid-nineteenth century-Ernü yingxiong zhuan 兒女英雄傳 (Tales of young heroes), Huayue hen 花 月痕 (Traces of moon and flowers), and the slightly later Qinglou meng 青樓夢 (Dream of the green chamber) - it shares the feature of portraying a world that is an ultimately stable and invulnerable entity the heroes and heroines of which are lovers who embody impeccable standards of chastity and virtue. In their relative obliviousness to their historical context, moreover, these novels pour their intensity into romantic exemplars the most exemplary of whom are

德 drama, Nan wanghou 思上后. For other instances in the Qing, see episodes in Taohua ying 挑花影, ru Lou Chun 干. 樓春, Rulin waishi 懦林外迆, Honglou meng 紅 樓荘, and stories by Pu Songling 蒲松齡, Yuan Mei 袁枚, and Ji Yun 紀咆,

${ }^{2}$ As we know from numerous sources. See, for example, Wu Cuncun 哭你你, Ming Qing shehui xing'ai fengqi 明清社會性愛風氮 (Beijing: Renmin wenxue chubanshe, 2000), Ch. 14, who provides the most complete information about these sources, and Colin Mackerras, The Chinese Theatre in Modern Times: From 1840 to the Present Day (London: Thames and Hudson, 1975), Chinese Theater: From Its Origins to the Present Day (Honolulu: University of Hawaii Press, 1983), and Chinese Drama: A Historical Survey (Beijing: New World Press, 1990). Male same-sex love in the Qing normally did not suffer harassment or punishment unless criminal behavior was involved. But it was the subject of legal concern, and was in some instances a target of condemnation. On the legal status of these practices in the Qing, see Vivien $\mathrm{Ng}$, "Ideology and Sexuality: Rape Laws in Qing China," Joumal of Asian Studies 46 (1987): 51-70, and "Homosexuality and the State in Late-Imperial China," in M. Duberman, M. Vicinus, and G. Chauncey, Jr., eds., Hidden from History: Reclaiming the Gay and Lesbian Past (New York: Penguin Books, 1989); Sophie Volpp, "The Male Queen: Boy Actors and Literati Libertines" (Ph.D. diss., Harvard University, 1995); Matthew Sommer, "The Penetrated Male in Late Imperial China: Judicial Constructions and Social Stigma," Modem China 23.2 (1997): 140-80, and Sex, Law, and Society in Late Imperial China (Stanford: Stanford University Press, 2000). At the same time, prominent literati held that homoerotic desire was a natural disposition and was as fully deserving of fair attention and even admiration as heteroerotic desire. See, e.g., Volpp, "The Male Queen," and Wu, Ming Qing shehui xing'ai fengqi, 157-58, especially regarding the affair between Chen Weisong 陳 維 秝 and the actor Yunlang 雲 郎; Michael Szonyi, "The Cult of Hu Tianbo and the Eighteenth-Century Discourse of Homosexuality," Late Imperial China 19.1(1998): 1-25; and Giovanni Vitiello, "The Forgotten Tears of the Lord of Longyang: Late Ming Stories of Male Prostitution and Connoisseurship," in Peter Engelfriet and Jan de Meyer, eds., Linked Faiths: Essays on Chinese Religions and Traditional Culture in Honour of Kristofer Schipper (Leiden: Brill, 2000), 227-47 — many thanks to Giovanni Vitiello for helpful comments on early versions of this paper and for supplying me with early versions of his work. 
women of spectacular beauty and talent, and men who either pale before these women or who themselves embody characteristics of the talented woman. Precious Mirror particularly stands out among these and other novels of the period in terms of its homoerotic appropriation of the late Ming concept of qing 情 and the idealization of the feminine. Within this literary-aesthetic inheritance, it is the status of femininity and chastity that will demand our attention in a novel in which the ultimate feminine figure is the virginal boy actress. Like the talented woman famous since the late Ming, he is an ideal figure when it comes to portraying the subject at odds with the social order. His sublimity consists of his ability to act defiantly and decisively under extreme conditions, regardless of danger or disadvantage to himself.

The two especially notable themes in the homoerotic appropriation of qing are, first, the idea of "sublime love," the words I will use in the context of Precious Mirror to interpret the otherwise polysemous qing, whose commonest equivalents are feeling or passion. ${ }^{3}$ The other theme is the ethics of equality, which derives from the emphasis on relationships of equality over those based on hierarchy, an emphasis that is one of the most identifying components of qing as it is defined in the Ming and Qing. The particular application of the ethics of equality in Precious Mirror is unique and surprising. In the homoerotic relationship idealized in the novel, lovers who are rigidly separated in terms of status nevertheless experience a sublime love which necessarily results in the liberation of the man of lower status, the dan 旦 or the boy actor of female roles in Kun opera (known as Kunqu 崑 曲). The novel builds up to this liberation, which it prominently stages toward the end as the dan collectively abandon their indentured status as Beijing opera singers. The uniqueness of Precious Mirror lies in its extension of the egalitarian implications of the qing aesthetic into a realm of practical realism whereby the lover of the dan acts upon an ethical obligation to free the dan. Precious Mirror presents this act neither through anything like an articulated manifesto promoting reform in real society, nor by belonging to some milieu in which such a program of reform was already in existence. ${ }^{4}$ Instead the novel works

${ }^{3}$ Martin Huang, "Sentiments of Desire: Thoughts on the Cult of Qing in MingQing Literature," CLEAR 20 (1998): 153-84, and Maram Epstein, "Reflections of Desire: the Poetics of Gender in Dream of the Red Chamber," Nan Nii 1.1 (1999): 64106; both discuss the history and interpretation of the word.

4 Andrea Goldman's study of zidi shu s-弟召: (scion's tales) supplies evidence regarding a strong sense of "peer identity between performers/writers and audi- 
out the relationship of sublime love step by step within its own appropriation of the theme of qing and the idealization of the feminine.

Because of the relative obscurity of the novel, it needs a detailed introduction beginning with an account of its plot and characterization. Precious Mirror takes place among young men of elite status who, besides preparing themselves for the marriage and career dictated by their social milieu, have a keen fascination for opera, especially its beautiful boy actresses. Each of the central heroes has a special boy whom he loves, but Mei Ziyu 梅子玉 in particular loves a boy named Qinyan 琴言 (surnamed Du 杜), whom he barely meets but who likewise feels an immediate and overwhelming love for Ziyu. An opposite cast of characters consists of ugly and untalented men, including an especially profligate and villainous man named Xi Shiyi 奚十一. Xi so craves the company of Qinyan that Qinyan is forced to seek refuge as a retainer in the household of a young opera connoisseur who, although handsome and talented himself, is incapable of appreciating the true feelings of someone like Qinyan. The love between Ziyu and Qinyan is constantly thwarted, meanwhile, until they finally manage to meet in a special place and spend their most intimate time together. This meeting occurs after Qinyan, through the help of well-placed opera patrons, has obtained his freedom and has become the adopted son of a famous literatus. Ziyu has by then married a beautiful and talented woman who looks like Qinyan and who appreciates the bond that Ziyu has had with Qinyan during his ordeal of love.

Who in particular are the young lovers of the novel? The homoerotic relationship idealized in Precious Mirror is between the young and upcoming scholar of privileged background, commonly called the mingshi 名士 (such as Mei Ziyu), and the exquisitely beautiful boy actress, known as the $d a n,{ }^{5}$ that is, the fifteen- or sixteen-year-

ences for zidi shu." The zidi shu came into their own in Beijing and elsewhere in the nineteenth century and differed from the opera performing context especially in the greater uniformity of classes among all involved. Another difference is the lack of the need for a cross-dressed boy actor in zidi shu. As Goldman shows, even a "grizzled" male opium addict could enact either a man or a woman in erotic encounters. Performance was more important than the actor's appearance. Thus the context for the possibility of something like the egalitarianism I am discussing here did exist at the time of the creation of Precious Mirror. See Andrea Goldman, "The Nun Who Wouldn't Be: Representations of Female Desire in Two Performance Genres of 'Si Fan," Late Imperial China 22.1 (2001): 71-138, especially 114, 117-19.

5 The mingshi, literally "famous scholar," can be referred to as young scholar 
old boy at the peak of perfection in his years as actor of female roles in Kun opera (including Qinyan and eight or so others). Although they are unequal in terms of social status, they enact a fantasy of equality which is central to the rarefied quality of their love. The dan is virtually an indentured servant who must obey his opera master and who is for all intents a prostitute in the eyes of certain patrons who seek and in some cases demand his favors. ${ }^{6}$ Thus one of the prime qualities of the true lover of the dan is that he understands the dan from the inside, that is, as if the lover had been himself thrown into the human market and sold as a helpless boy into an opera troupe. What this means in particular contrast to the scene of vulgar relationships between other men of high status and boy actresses or boy prostitutes is the following: if you, the mingshi, are my true lover or, to use the classical term, my zhïi 知已 (that is, soul mate), then I can be myself with you. There is no behavior on command - such as serving you your opium pipe, giving you massages, or presenting myself to you sexually. I can tell you everything that I feel, and you will hear me, especially when I tell you how trapped and unhappy I feel in my position as dan.

If these lovers are equal, however, how do we interpret the extreme valorization of the feminine characteristics of the dan which he must ultimately give up? What, moreover, do we make of the significant role of women in the novel and the overlap but also occasionally suggested rivalry between them and the dan? Our approach to the status of both femininity in the dan and of women themselves in Precious Mirror requires a consideration of the concept of qing that the novel inherits from earlier literature. The position of the female

or literatus, but also as the dan's patron. The dan was also called the mingdan 名日 (parallel to mingshi, but resonating with mingï 名妓 “famous courtesan" as well) or by the diminutive xiaodan 小 $\Pi$.

${ }^{6}$ Colin Mackerras says that the high period of the role of the dan in Kun opera was between 1790 and the 1830 s, after which the emphasis shifted from boy actors toward an interest in more mature male roles, "including military heroes and statesmen"; Chinese Drama, 67. But the south, especially Jiangsu and Anhui, continuously supplied dan to Beijing until the Taiping Rebellion in the 1850s and 1860 s interrupted that connection (Wu, Ming Qing shehui xing'ai fengqi, 182-83). Famous dan continued to exist well into the twentieth century. The system of indenture, according to Mackerras, thrived because of a combination of economic decline and population growth which by the end of the eighteenth century caused many parents or other relatives to find strong reason to sell a boy into an opera troupe. The system existed until abolished under the People's Republic of China in the 1950s (Chinese Drama, 201-02). 
subject has long been idealized among Chinese literati as a refuge of authenticity outside the crass world of male politics. ${ }^{7}$ During the late Ming, such idealization intensified as literati created what was virtually a cult of qing. This appropriation of the feminine had on the one hand an ideological, even political, component in the form of a critical attack upon orthodox Neo-Confucianism. ${ }^{8}$ During the Ming-Qing transition, the woman, especially the courtesan, became further idealized as a figure of refuge and resistance for Ming loyalists. ${ }^{9}$ Although the political component of the qing ideology weakened in later literature, including Pu Songling's Liaozhai zhiyi 聊齋志異, Cao Xueqin's 曹雪芹Honglou meng, and Chen Sen's Precious Mirror, the potential for political and ethical effects persisted, as we see in what I am calling Precious Mirror's ethics of equality.

On the other hand, besides its political ramifications, the qing aesthetic also carried with it a fascination with illusion and dalliance, especially in the form of the play with the crossing of gender. ${ }^{10}$ Precious Mirror is a continuator in a long line of Ming and Qing works which experiment with the volatility of and crossing between masculine and feminine characteristics. Indeed, as Maram Epstein describes, the aesthetics of masculine and feminine in these works have such varied expression that we must speak of a "gender continuum."11

\footnotetext{
${ }^{7}$ For detailed discussions and summaries of this history and its significance for the cult of qing, see Dorothy Ko, Teachers of the Inner Chambers: Women and Culture in Seventeenth-Century China (Stanford: Stanford University Press, 1994), Ch. 2; Anthony $\mathrm{Yu}$, Rereading the Stone: Desire and the Making of Fiction in Dream of the Red Chamber (Princeton: Princeton University Press, 1997), 56-66; Huang, "Sentiments of Desire"; and Epstein, "Reflections of Desire."

"See Epstein, "Reflections of Desire," 82.

9 On the courtesan in late Ming literati culture, see Li Wai-yee, "The Late Ming Courtesan: Invention of a Cultural Ideal," in Ellen Widmer and Kang-i Sun Chang, eds., Writing Women in Late Imperial China (Stanford: Stanford University Press, 1997), 46-73.

10 Numerous scholars have dealt with these aspects. See, for example, Li Waiyee, Enchantment and Disenchantment: Love and Illusion in Chinese Literature (Princeton: Princeton University Press, 1993), 47-50 (on illusion); Epstein, "Reflections of Desire," 90-95; and Giovanni Vitiello, "Exemplary Sodomites: Chivalry and Love in Late Ming Culture," Nan Nii 2.2 (2000): 207-57 (the latter two both on gender fluidity).

11 In her words, speaking of Honglou meng in particular, gender "occurs along a continuum with a seemingly infinite possibility of positions and variations," although with a decided valorization of the feminine ("Reflections of Desire," 90). Along the same lines, she also says, "Indeed, it could be argued that the complementary manipulation of gender and gendered characteristics is one of the signature aesthetic traits of Chinese literature written during and after the late sixteenth century" (86).
} 
The type of men favored in this aesthetic embody feminine looks and qualities, like the heroes of Precious Mirror. In numerous works, moreover, heroines act or dress like men, and are as talented as men or more so. The primary effect of such gender fluidity is to dissolve the distinctions between high and low status, of active and passive roles, and prescribed male and female positions in general. ${ }^{12}$

I want to argue, however, that the valorization of the feminine is still more than a matter of dissolving social and aesthetic boundaries. If we look at the ontological aspect of the role of the woman in the qing ideology, we must realize that she comes to represent an ideal subject in ultimate situations, whether it is the fall of the Ming or the oppression of the dan (or the courtesan) by vulgar men and villainous masters. She is an ideal figure when it comes to portraying the problem of subjection in the symbolic order. She embodies purity and transcendence, qualities which endow her with an ability to act decisively and with utter disregard for material concerns. Qinyan's defiance of vulgar patrons is an example of such purity, as is also his refusal to participate cheerfully in social gatherings. The woman and her male impersonators are sublime figures, in short, who stir their admirers with what amounts to sublime love.

This last point, the sublimity of the feminine aura, brings us to the interpretation of the term qing that I mentioned previously. Although qing has numerous facets that forbid any single-word translation, the main sense that the author of Precious Mirror in particular pursues is best captured by the two words "sublime love." These words crystallize my approach to the novel, which is summed up by the several

12 As Ko writes, qing can even be referred to as a "gender equalizer." But see also her qualification of these words (Teachers of the Inner Chambers, 111-12) and her discussion of the subtle differences between male and female perspectives on qing (78-79). See also Li, "The Late Ming Courtesan"; Katherine Carlitz, "Desire and Writing in the Late Ming Play Parrot Island," in Widmer and Chang, eds., Writing Women, 101-30; and Vitiello, "Exemplary Sodomites," who sums up this argument by referring to Ko and to K'ang-i Sun Chang, The Late Ming Poet Ch'en Tzu-lung: Crises of Love and Loyalism (New Haven: Yale University Press, 1991). Maram Epstein says of Jia Baoyu 崱算 F. that he "manages to reduce all of his relationships to an equal bond of friendship and thus progressively deconstructs orthodox social structures" ("Reflections of Desire," 91). Drawing on Kao Yu-kung and Li Wai-yee, she also links this deconstructive attempt to "the traditional lyric impulse of dissolving boundaries between self and other. This aesthetic ideal enabled the individual to transcend the restrictions of the hierarchical relationships prescribed by ritual and replace them with the affective bonds of qing" (90). 
aspects that I will explore in order to elucidate the sense of the sublime, a word that at root can be defined as that which is askance from the concrete or the real. First, we must examine the rarefied, sublime quality of the passionate bond and then also note the special importance in this bond of the value of chastity. Defining chastity will in turn entail a consideration of its obverse in the form of the vulgar erotic, or what I will also call the "reverse" sublime. With these areas clarified, we will be better equipped to approach the status of femininity in the novel, in particular to understand the ontological aspect of the woman and the dan insofar as they constitute ideal subject positions in ultimate situations. These considerations will switch between the woman and dan as idealizations, on the one hand, and the woman and dan as real figures in the novel, on the other. The women in particular at times appear to rival the dan and even to symbolize a masculine presence, but they also resemble the dan as they embody the ideal of superior femininity that is central to the concept of qing.

I will conclude by returning to a central focus of the novel, the most defining example of feminine superiority and the best illustration of the feminine subject position in its ontological aspect, namely, Qinyan's act of "leaving his profession," gaihang 改行. Qinyan leaves the opera troupe and becomes the adopted son of an erudite, sonless widower who will now train Qinyan as a literatus. But before this, Qinyan was trapped in his profession and was only able to leave it because of the intercession of benefactors who finally understood the defiance of Qinyan's hatred of being a dan. That defiance comes out most strongly when he takes the great risk of rejecting the lustful advances of the wealthy and powerful Xi Shiyi. In this single instance, although he still suffers hardships afterwards, Qinyan nevertheless makes the clearest case of all for both himself and the other dan to liberate themselves. "Changing professions" in this case also means dying, as it were, by making a new appearance in a different station in the form of a symbolic rebirth. The possibility of this rebirth has the retroactive effect of revealing the fact that the dan as a category or lot of human beings is an impossible fantasy. In ethical terms, the impossibility of this fantasy means that if the young scholar truly loves the dan, then he must no longer expect the dan to be a dan. As a demonstration of this point, all the central boy actresses of the book gather in the final chapter to burn their costumes and other paraphernalia. They are especially triumphant as they emerge from this 
past, moreover, because they have all succeeded in maintaining their virginity $(59.767) .{ }^{13}$

The Novel's Setting in Beijing

The novel's setting in Beijing features an urban male elite consisting of refined young men of letters who serve or prepare to serve in the official bureaucracy. But they stand apart from the general body of literati in that these men of extreme polish and high taste find a mutual identity in their connoisseurship of and love for dan. As they discuss in Ghapter 1, the best dan converge upon Beijing, making that city the consommate location for their cherished pastime. Within this urban setting, the characters of the novel travel around the city, both within and outside its enormous walls, visiting friends, eating in restaurants, gathering at parties in Xu Ziyun's 徐子雲 garden (outside the walls), attending opera, and frequenting the quarters where the dan live. They also meet or pass each other in the streets and lanes of Beijing, as in the reverberating scene in which Ziyu and Qinyan first catch a glimpse of each other in passing carriages (1.13).

The network of connections linking these connoisseurs relies on the proximity of the greater Beijing environment (that is, the area both inside and outside the city walls). ${ }^{14}$ Such an urban phenomenon has a long history in China, starting at least with the Kaifeng and Hangzhou of the Song dynasty, but has a distinctly Beijing character by the eighteenth and nineteenth centuries. ${ }^{15}$ Besides the dra-

${ }^{13}$ Leaving the profession, also called gaiye 改業, is by no means unheard of for people like actors and courtesans, especially when they grow beyond their prime years. Gaiye can be found, for example, in a story by $\mathrm{Pu}$ Songling in which an actor is urged by his father to change professions. See "Wei Gongzi" 袁公子, in Zhang Youhe 張友鶴, ed., Liaozhai zhiyi (Shanghai: Shanghai guji chubanshe, 1978), 11.1572. Prior to the Yongzheng 雍 止 Emperor's abolition of the laws differentiating jian 賤 and liang 良 categories of the population, it was illegal to change professions, although people managed to do so anyway. By the time of Precious Mirror, changing professions was mainly a matter of monetary contract (although of course other nonmaterial bonds could also play a major role). The boy actor, like the courtesan, had to buy his freedom from the person who owned him. For more details on the laws of status, see Sommer, Sex, Law, and Society in Late Imperial China.

14 The fact that the city gates close every night influences the activity of the characters, as in the case of one young connoisseur who decides to leave a performance earlier than he would like because of the necessity of getting home before the gates close (25.311-12).

${ }^{15}$ See Mackerras's brief outlines of the rise of Kun opera in these times, especially after 1790 (Chinese Theater, 102-03, and Chinese Drama, 65-70). 
matic texts themselves, a considerable body of literature came out of this milieu about which we still know relatively little, for example, poetry, letters, personal notes, and evaluations of actors and the various aesthetic aspects of opera. ${ }^{16}$ Precious Mirror emerges from this context of an urban male elite that prides itself on its purity and authenticity in the form of its devoted appreciation of the beauty of the dan.

Two notable components of this sense of purity and authenticity link the novel with other works of its period: 1) a repugnance for boorishness and decadence, which are repeated targets of satire, and 2) an aura of insularity, which is exemplified by the novel's sole concentration on these men and their lives to the exclusion of any mention of the social and political turmoil of those times. The quintessential boor is the wealthy opium addict from Guangdong, Xi Shiyi, who makes his money trading in foreign goods, perhaps including opium. Besides the many descriptions of opium smoking itself, he is the only major representation in the novel of the foreign outside of China, and at that the representation is sparse and indirect. ${ }^{17}$ For example, he smokes a type of opium, heitu 黑土 (black dirt), which as was well known at the time came from India via British or Indian merchants. ${ }^{18}$ The novel's silence otherwise about the opium issue and the other crises of those times is, as I have said, not unique to Precious Mirror. Emü yingxiong zhuan and Huayue hen of approximately the same pe-

${ }^{16}$ See the collection compiled by Zhang Cixi 张次溪, Qingdai yandu liyuan shiliao 清代燕都梨園史料 (Beijing: Zhongguo xiju chubanshe, 1991), who in the 1930s gathered many of these materials, which include a genre that consists of brief biographical evaluations of actors that can also be found reproduced in the first chapter of Precious Mirror.

17 That is, the novel never mentions that he buys his opium from foreigners, but instead relates laconically that his family has a yanghang 洋行 (18.231), i.e., a business which deals in foreign goods. He comes from Hainan Island in Guangdong and travels to Beijing in order to purchase an official title $(3.36,39-40)$. Since his father is a "merchant in foreign goods," that is, a yangshang 洋商, Xi Shiyi has the connections to deal in "foreign goods," yanghuo 洋貨, the sale of which earns him a great profit. He makes this profit, moreover, from a "foreign ship," yangchuan 洋 船 that docks in nearby Tianjin, which was one of five treaty ports by the time the novel was published (27.327). As in numerous other novels of the Qing dynasty, minor items of foreign origin also appear, such as a foreign painting (5.65) or a foreign-style room $(9.117)$.

18 On opium in nineteenth-century fiction, see Keith McMahon, "Opium and Sexuality in Late Qing Fiction," Nan Nï̈ 2.1 (2000): 129-79 (on opium in Precious Mirror, 147-48, 153-56, 157-8, 166-69). Heitu is an especially strong type of opium from Bengal commonly opposed to the milder baitu $\pitchfork \perp$ from Malwa. 
riod as Chen Sen's work, as well as Qinglou meng of a few decades later, all manifest a similarly insulated sense of purity and authenticity. ${ }^{19}$ Huayue hen and Qinglou meng in particular take the theme of qing to comparable heights of rarefied sublimity. The urban-centeredness of Precious Mirror is closely connected with its particular focus on the male homoeroticism of the world of Kun opera and is something that distinguishes it from these other novels. But all portray China as a self-enclosed entity the stars of which are qing-perfected people like the young scholars, their wives, and the boy actors. The repugnance for vulgarity and the exclusion of historical realities project a common sense of invulnerability that within a few decades will in both real and fictional form convert into a drive to focus on the later developments of those same historical realities.

Study of the Novel

The study of Precious Mirror of Boy Actresses - more literally called Precious Mirror for Ranking Flowers ${ }^{20}$ - has only recently recommenced. Lu Xun's and Zhao Jingshen's 趙景深 discussions from the early part of the twentieth century have been followed by a long hiatus. ${ }^{21} \mathrm{We}$ know that the author Chen Sen lived from approximately 1796 to 1870 and that he wrote the novel during the ten years between 1837

19 The reference to the Taiping Rebellion in Huayue hen is substantial, but the sense of insularity prevails because the problems of both the Taipings and of Western incursions are completely resolved by the end of the novel. In general, nineteenthcentury fiction up to the very late Qing does not engage in extensive reference to China's problems with foreigners. The main sign of the growing Western presence is the appearance of opium in these works beginning in about 1820 .

20 In Fin-de-siècle Splendor, Wang calls it Precious Mirror for Judging Flowers. My use of "Boy Actresses" is inspired by the novel Pei Yu Boy Actress, by George Soulié de Morant, originally 1925, which also takes place among actors and patrons in Beijing, trans. Gerald Fabian and Guy Wernham (San Francisco: First Alamo Square Press, 1991).

${ }^{21}$ See Lu Xun, A Brief History of Chinese Fiction (Beijing: Foreign Languages Press, 1976), 319-22, and Zhao Jingshen, Zhongguo xiaoshuo congkao 中國小說丵考 (Jinan: Qilu shushe, 1980), 454-63. For other brief studies, see Liu Ts'un-jen, Chinese Popular Fiction in Two London Libraries (Hong Kong: Longmen Bookstore, 1967), 134-37, and Kong Lingjing 孔另境, “Pinhua baojian shiliao”品花寶鑑史料, reprinted in the 1986 Taibei edition, 801-06. More recent references to the novel include Lei Yong 雷乓 “Xiaxie xiaoshuo de yanbian ji qi chuangzuo xintai”狄邪小就的

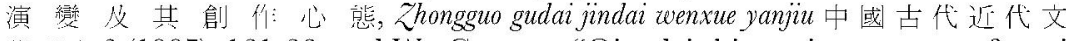
學僻 2 (1997): 131-36, and Wu Cuncun, "Qingdai shiren xiayou xutong fengqi xulüe”清代士人咞優蓄苹風氣敘略, Zhongguo wenhua 中國文化 15, 16 (1997): 231-41, and Ming Qing shehui xing'ai fengqi. 
and 1848 , but may have started it earlier, ${ }^{22}$ and published it in 1849 . Some, perhaps many, of its contents refer to historical realities, including especially the two lovers Tian Chunhang 田春航 and $\mathrm{Su}$ Huifang 蘇恵芳, who are based on real figures. ${ }^{23}$ In general, although the novel was highly esteemed by some in the late Qing, it receives little if any acclaim anymore. ${ }^{24}$ Along with two recent studies, however, Wang's Fin-de-siècle Splendor and Chloe Starr's "Shifting Boundaries: Gender in Pinhua baö̈an," I would like to take Precious Mirror more seriously. ${ }^{25}$ First, Wang's excellent discussion raises several questions for which I will suggest alternate solutions and provide further exploration. In particular, he implies that the novel "gravitate[s] toward a conservative discourse in which sexuality is safely compartmentalized." "26 As severe as the compartmentalization indeed is, it nevertheless need not be read in such a conservative light. In short, the young scholar's chastity and the dan's virginity can be seen as signs not of conservative repression but of radical liberation. Wang also treats the idealization of women and what he sees as the apparent contradiction between this idealization and both the author's effective dismissal of real women and his "usurp[ation of] feminine discourse for men's use" (69). He charges that the novel's "happy ending underlies nothing more than a male-centered fantasy" (69, 70-71), and repeats (although he does not entirely endorse) the "common charge" against the novel "that it reads too much like an ordinary 'straight' romance" (66). These statements all have their validity, as I will admit below, yet something else lurks in Precious Mirror that, despite its blanket idealizations and luxurious indulgence in male fantasy, nevertheless points toward the void of male fantasy and thus of the idealization of women as well. At the same time,

22 See Zhao, Zhongguo xiaoshuo congkao, and Wang, Fin-de-siècle Splendor (including his citations, 357, n. 15).

${ }_{23}$ See Wu, Ming Qing shehui xing'ai fengqi, 162-63, 165; Wang, Fin-de-siècle Splendor, 63; and Zhao, Zhongguo xiaoshuo congkao, 457-59.

${ }^{24}$ For instance, Stephen Cheng considers it mediocre, as does Wang, though Wang gives it more credit (see below); Wang, Fin-de-siècle Splendor, 62, which refers to Stephen Cheng, "Flowers of Shanghai and the Late Qing Courtesan Novel" (Ph.D. diss., Harvard University, 1979).

25 See Chloe Starr, "Shifting Boundaries: Gender in Pinhua baojän," Nan Nü 1.2 (1999), 268-302.

${ }^{26}$ Wang, Fin-de-siècle Splendor, 56. See also his statements about the author's "anxiety to smooth over the dialectic between ethical imperatives and erotic temptations" (64-65) and how the author tries ("too hard") "to deal with depravity in strict, virtuous terms" (64). 
Wang makes the interesting observation that Precious Mirror "sheds light, however unexpected, on woman's positions in the formation of romantic conventions" (62). The word "unexpected" perhaps refers to the novel's veiled (that is, nonexplicit) reference to romantic conventions as things that are formed and thus contingent or arbitrary. Nevertheless, as ambiguous and inconsistent as Precious Mirror often is (here I agree with Wang), it is more aggressive in exposing these conventions and in upholding a radical discourse of love going back to the late Ming than we may at first think.

Starr's more detailed appraisal of Precious Mirror is similar to Wang's in its emphasis on the novel's normative compartmentalization of masculine and feminine traits and its ultimate adherence to safe male centrality. Likewise, she notes several of the novel's troublesome ambiguities, such as the ending in which the young men marry women who look like their male lovers ("Shifting Boundaries," 224), or the revelation that one of the boy actresses was a woman in his former life (298). But in underscoring the marginalization of women and of femininity in general, she risks attaching too much significance to the superficiality of the attributes adopted by boy actresses in their female impersonations. ${ }^{27}$ Femininity in Precious Mirror is not merely a set of attributes, I would argue, to be discarded when circumstances allow someone to assume a more assertive (that is, masculine) role. It also involves a keen awareness of the state of subjectivity in itself, that is, an awareness of the entrapment within subjectivity and of the simultaneous existence of possibilities, though often limited, of liberation and transcendence.

Many other studies of homoeroticism in Europe, Japan, and China take as their basic premise Starr's assumption of the disassociation between gender and sex that is implied by the boy actor's female impersonation. Femininity in a novel like Precious Mirror, in other words, appears as something that is performed and that can be detached from the female bodies that normally perform it. ${ }^{28} \mathrm{I}$ make the same

$27 \mathrm{Wu}$ Cuncun also tends in this direction, at the same time demonstrating the various superficial aspects of the novel's egalitarianism (Ming Qing shehui xing'ai fengqi, 208-11).

${ }^{28}$ For studies of this topic in the European context, see, for example, David M. Halperin, "One Hundred Years of Homosexuality," in One Hundred Years of Homosexuality and Other Essays on Greek Love (New York: Routledge, 1990), 15-40, and Carol S. Vance, "Social Construction Theory and Sexuality," in Maurice Berger, Brian Willis, and Simon Watson, eds., Constructing Masculinity (New York: Routledge, 1995), 37-48. For studies of Japanese male-male sexuality of approximately the 
assumption, but add - to emphasize my point again - that Precious Mirror is far from demonstrating the mere performativity of feminine roles in terms of external resemblances. The novel instead dramatizes a feminine position that is arrived at neither by deliberate objective means such as costume or gesture, nor by the biological determination of sex. The subject in this position undergoes a type of transformation that brings about decisive action, whether in the form of grand refusal or headlong mission. The importance of qing in such situations has to do with both the special tonality (grand, headlong) of the way in which the subject takes on her or his particularly chosen role and with the sublime aura that persists regardless of the attributes and roles that are figured through the complexities of the socio-symbolic order.

\section{Part II Between Chaste and Erotic}

The Sublime is the Erotic

For my explanation of the implications of femininity and sublime love in Precious Mirror, it is necessary to consider two main points. The first is the supreme importance in the novel of the chastity of the relationship between the young scholar and the dan. It is a mistake to think either that this chastity is simply hypocritical (that is, that in some sense they "really want to" or actually secretly "do" have sex) or that it is dead serious and is to be taken as rigid denial. In fact, as pure as it may seem, this chaste love is the most intensely erotic of all precisely because of the unrelenting delay and foreclosing of the sexual act. Precious Mirror's theme is that any direct representation of sex between the two lovers will always fail to capture

same period as Precious Mirror, see Gary P. Leupp, Male Colors (Berkeley: University of California Press, 1995), and Gregory M. Pflugfelder, Cartographies of Desire: Male-Male Sexuality in Fapanese Discourse, 1600-1950 (Berkeley: University of California Press, 1999). Studies of the Chinese context include Carlos Rojas, "The Coin of Gender in Pinhua baojian and Jinghua yuan" (Paper presented at the Symposium "From the Late Ming to the Late Qing: Dynastic Decline and Cultural Innovation," Columbia University, November, 1998); Volpp, "The Male Queen," 19394; and Vitiello, "The Dragon's Whim: Ming and Qing Homoerotic Tales from The Cut Sleeve," T'oung Pao 78 (1992): 341-72; "The Fantastic Journey of an Ugly Boy: Homosexuality and Salvation in Late Ming Pornography," Positions 4.2 (1996): 291-320; "The Forgotten Tears of the Lord of Longyang," and "Exemplary Sodomites." 
the truly sublime passion of their love. That sublimity lies elsewhere, as we will see below, beyond the vulgar opposition between indulgence and restraint.

The second point that will illuminate both the status of the feminine and the meaning of chastity in the novel is the analogy between the same-sex couple of the scholar and the dan and the opposite-sex couple of the scholar and the beauty. Both the scholar-beauty tradition of the Ming and the Qing and the influence of Dream of the Red Chamber are vital to the formation of Precious Mirror, especially if we consider the late Ming concept of qing and the theme of the superiority of the woman as figured in the character type of the "talented woman," cainü 才女, or the "beauty," juaren 佳 人. In Precious Mirror the theme of the superiority of women translates into both the superiority of the dan over the woman and the superiority of the feminine over the masculine. The juxtaposition and rivalry between women and dan in Precious Mirror is a topic I will discuss later, while for now I will concentrate on the sublimity of the chaste dan as a metaphor of the "beauty." The other key element of the model of the scholar and the beauty is the way they resemble or mirror each other, especially in the crossing of gender characteristics. In line with this tradition, Precious Mirror features the sublime love between two young men in a way that suggests parity between these status unequals and that, moreover, imitates the rule of procreation while sublimating the drive of the male penetrator. That is, the mingshi sees to the welfare of the dan in a fatherly way by helping the latter exit the world of opera bondage and, in Qinyan's case, adopting him as son. The sublimation of the drive of the male penetrator is a move which takes the body out of circulation in the vulgar world of exploitative relations between penetrator and penetrated.

What is the nature of this chaste, rarefied love as described in Precious Mirror? Most obviously, the emphasis on chastity is a sign of a relationship cultivated for more than mere sex. ${ }^{29}$ Chastity in the malefemale relationship was already well established in fiction from the early Qing beauty-scholar romance onward, including Dream of the Red Chamber and a number of its sequels of the late 1700s and early

29 A situation also found in the case of the practice of male love (shud/o 衆道) in Edo Japan (Pflugfelder, Cartographies of Desire, 43). As Pflugfelder says, sexual intercourse was "not even a sine qua non element of the wakash/u-nenja relationship" (若祘/念者, 43 ). 
1800 s. ${ }^{30}$ In Precious Mirror as in these other works, chaste love is something rare and hard-won, and thus not available to the vulgar crowd. However, Precious Mirror emphasizes the fact that only those who remain utterly committed to the notion of this love can come near to attaining it, but that at the same time it is also the most unattainable love even for the finest people. The lovers cannot even succeed in getting together, as with Ziyu and Qinyan, who for a long time only hear about each other but never get to meet except by the rarest and most fleeting chance. When consummation finally occurs, it is intermittent and, when it climaxes, never takes the form of intentional touching, much less sex.

At the same time, the rarefied ideal of knower-of-the-self passion needs its vulgar opposite in order to succeed in evoking the true quality of the sublime. The novel's explicit staging of sex as always only a vulgar act is a way of sustaining the fantasy of ecstasy that occurs elsewhere. Precious Mirror follows the well-established narrative method in Ming and Qing fiction and drama of alternating between chapters (or scenes) about its refined characters and chapters about the ugly and the vulgar. Like its many Ming and Qing predecessors in both fiction and drama, Precious Mirror in effect demonstrates that sublime passion cannot exist without vulgar dissipation. We can even say that the rarefied moments cannot rejoice without their vulgar, pornographic counterparts. Precious Mirror is exuberant as it roams from scene to scene of opium debauchery, intense anal intercourse, vengeful stuffing of anuses with irritants, and vaginas with hair that looks like grass or like a beard. The person who sees what the writer of Precious Mirror displays has seen and heard everything sensational and newsworthy in every corner of the world of Kun opera.

The actual demonstration of this chaste love occurs via identifying words and expressions, character portrayals, and episodes. Although it is a love which cannot be realized in the flesh, it is right here in our midst, as various assertions in Chapter 1 make clear. Quoting a famous motto used in numerous Qing works to describe the superiority of women to men, a young scholar declares that the

30 See, for instance, Chen Shaohai’s 陳少海 Honglou fumeng 紅模復夢 (Beijing: Beijing daxue chubanshe, 1988), that is, Return to Dream of the Red Chamber, written ca. 1799, first published 1805. This sequel creates what amounts to a form of male chastity in counterpart to female chastity and repeatedly dramatizes chaste but intimate interactions between Baoyu's reincarnation and his numerous wives. These interactions are accompanied by the narrator's comments about the fact that Baoyu is all qing and no se 色 (see 13.139-40 and 26.287). 
“cosmic sublime spirit" (tiandi zhi lingxiu 天地之靈秀) that is found in the superior "beauty" and no longer in men can in fact be found in men after all, the most beautiful of whom are Beijing's famous dan (1.9). ${ }^{31}$ The young hero, Ziyu, is himself already this beautiful without "adding powder" (1.2). ${ }^{32}$ With just these details in the first pages of Chapter 1, Precious Mirror already proclaims that men can love other men and that women and adornment are in effect superfluous and artificial in contrast to the reality of the beautiful nonpowdered man right before one's eyes. ${ }^{33}$

Of course, this beauty is strictly for the eye only, as Xu Ziyun says to his wife (Chapter 11). To love only women is to be "lustful" (hao yin 好淫, 12.148). Thus when $\mathrm{Xu}$ is with his favorite dan, Baozhu 寶珠, Xu has no desire whatsoever for sex (que wu xiexia zhi nian 卻 無蓺狎之念, 5.58). When Tian Ghunhang and his favorite Su Huifang spend all night together, Chunhang suppresses "deviant thoughts" (xienian 邪念, 14.171). In a quintessential test of how beautifully the two avoid physical passion, when Chunhang and Huifang's faces unintentionally touch, Huifang blushes, and Chunhang temporarily loses control of himself (14.171). Huifang's blush is like a tumescence. The sex that could occur, moreover, would be wondrous, for when they touched in that moment an "extraordinary fragrance penetrated Chunhang's nostrils and went straight to his heart." The couple Qinyan and Ziyu are purer yet. "Better than all the scholars and beauties in the world" (22.280), they finally reunite after Qinyan has been freed from being a dan and has gone through further harrowing experiences. They sleep in the same bed, using the same pillow, "with their clothes on," and forgetting that any "suspicion" might arise because of this, although Qinyan feels “awkward" (jucu 局 促) the next morning when a friend of theirs sees them as "they lie with heads drawn together, talking in tones that only each other could hear" (59.765-66).

31 For a discussion of this famous allusion, see McMahon, Misers, Shrews, and Polygamists, 184-85, and Louise Edwards, "Women in Hongloumeng: Prescriptions of Purity in the Femininity of Qing Dynasty China," Modern China 16.4 (1990): 407 29 , especially $411-12$.

32 That is, not only the powder women would put on but the powder that male beauties in the period of the late $\mathrm{Han}$ and Six Dynasties also famously wore. See Wang Yao $上$ 瑤, “Wenren yu yao" 文人與 楽, in Wang Yao, Zhonggu wenxue shilun 中古文學义! 論 (Beijing: Beijing daxue chubanshe, 1986), 141-43.

33 These ideas are not new to Precious Mirror. See Volpp's discussion of late Ming and early Qing texts, especially concerning the "competition" between the boy actor and the courtesan; Volpp, "The Male Queen," 7, 10, 68, 92, 150. 
But two questions now come up: is the chaste really so chaste, and why is there such prominence given to the explicit portrayal of socalled vulgar sex? To answer these, we need first to examine the fact that there is no high erotic in Precious Mirror. When Ming and Qing novels want to portray sublime love that is also sexual, they have a rich tradition in the form of the high erotic style from which to write adumbratively, euphemistically, and elegantly of actual acts of sex. This high erotic also includes the high homoerotic, as seen in the late Ming story collections Bian er chai and Kichun xiangzhi. ${ }^{34}$ In these works, as Vitiello writes, the "lofty scenario of exquisite sexuality sported by the elite" contrasts with the vulgar, mercenary, and grotesque scene of dissipation. ${ }^{35}$ To engage in such homoerotic relationships is a sign of one's greater refinement ${ }^{36}$ even in the case of mainly heterosexual men who nevertheless frequent beautiful young boys and desire to be seen doing so. ${ }^{37}$ The point is that the portrayal of sexual acts between refined men who are in love is an option for the author of Precious Mirror, an option which other authors of high erotica exploited but which he for now did not. Furthermore, the relationship of the penetrator to the penetrated need not be hierarchized like that between the scholar and the virtually enslaved dan. Men of equally high status can be high erotic lovers in Bian er chai, Yichun xiangzhi, and numerous other Ming and Qing sources.

What we have in Precious Mirror, then, is a choice on the part of the author to focus on the fragile, ephemeral nature of the beauty of the dan. Chastity is not so much a denial or "repression" as a going further in the direction of - that is, of the sublime quality of male-male

${ }^{34}$ Which Vitiello and Volpp have discussed. See Vitiello, "The Fantastic Journey of an Ugly Boy" and "Exemplary Sodomites"; Volpp, "The Male Queen"; Keith McMahon, Causality and Containment in Seventeenth-Century Chinese Fiction (Leiden: Brill, 1988); and Wu, Ming Qing shehui xing'ai fengqi.

35 Quotation from Vitiello, "Exemplary Sodomites," 254; see also, Vitiello, "The Forgotten Tears of the Lord of Longyang."

36 Vitiello, "Exemplary Sodomites," 253-54. Vitiello also notes the "salvational" nature of this high passion, especially in the late Ming ("The Fantastic Journey of an Ugly Boy," 300), and makes the added point for us that in some works where there is a competition between male and female beauty (nanse 罗色 and nüse 女色 or between sex with men and sex with women), male beauty is deemed to be loftier. On the "competition," see also Volpp, "The Male Queen," 68, 92, 150. See Pflugfelder on the "debate" between the merits of courtesans versus boy actors in Edo Japan, a debate that he reminds us existed in ancient Greece, medieval Europe, and the Middle East as well (Cartographies of Desire, 59-60 and n. 96).

37 On this point see Wu, Ming Oing shehui xing'ai fengqi, 155-78. 
love. The aesthetic that Chen Sen adopts takes adumbration a step further so that Huifang's blush when Chunhang accidently brushes his face is already intensely erotic. The blush itself is a tumescence, as I have said, and that is all that this aesthetic needs. Qinyan and Ziyu sleeping head to head on the same pillow "with their clothes on" is already exquisite.

Another way to read the dan that helps us understand the significance of chastity is to compare him with the courtesan, that is, the mingi. ${ }^{38}$ The elite courtesan in the Ming and Qing was not someone with whom a patron automatically and for just a sum of money had sex. The layers of testing and approval that a patron or admirer had to pass through in order to be her intimate proved whether or not he was of high enough character. The dan is also like the courtesan in that he may be a person of originally good social standing who because of unfortunate circumstances fell into the profession of the opera troupe. The difference is that while a man might eventually marry a courtesan, in Precious Mirror the hero at best manages to keep the dan as a best friend after the hero's marriage to a woman. Still, the main point in common is that dignified, respectful relations are integral to the experience of the rarefied passion the literatus seeks with either the courtesan or the dan (in the same period as Precious Mirror, one finds this type of relationship between literatus and mingii in novels like Huayue hen and Qinglou meng).

Why, then, is there such an attention to the portrayal of vulgar sex? In the context of the emphasis on rarefied passion, actual sex is the quintessence of the concrete and the vulgar. The portrayal of sex in graphic detail in this case is like an attempt to see and to grasp sex in the concrete, whereas sublime passion occupies a vanishing point and can never be reduced to detail, which is always vulgar, monetary detail. ${ }^{39}$ In line with this emphasis on the sublime nature of qing, the scenes of vulgar lust, mainly centering on anal sex, focus on the onesidedness of this pleasure, its ridiculousness, or its violence. Still, as I have said, my point is that chastity in Precious Mirror is al-

38 See Vitiello, "Exemplary Sodomites," 255-56. Volpp discusses two types of actor/courtesan comparisons, one in which the actor is devious and streetsmart versus the courtesan who is a sentimentalized figure of the highest virtue ("The Male Queen," 161-62), the other in which, as seen in Bian er chai, the actor is modeled on the loyal and virtuous courtesan (166). Starr also emphasizes the parallels between the boy actress and the courtesan ("Shifting Boundaries").

39 See Rojas, "The Coin of Gender," on the monetary aspects of gender in Precious Mirror. 
ready erotic, and that this erotic quality derives in great part from its coexistence with the vulgar. This statement must be further qualified with a closer examination of so-called vulgarity. In the end, the vulgar itself also bears aspects of the sublime insofar as it is an integral part of the grand spectacle of love in the world of Kun opera.

Pornography and the World of Ugly People

The pornographic sections of Precious Mirror without exception focus on vulgar behavior among ugly, venal, and sometimes outright rapacious characters. The worst of them suffer ridiculous and terminal injury to their bodies, whether the penis (as with Xi Shiyi) or anus (as with Pan Qiguan 潘其 觀 and Ba Yingguan 巴英官). The small group of elite dan who maintain their priceless virginity are in constant danger of harassment and abuse at the hands of wealthy men whose resentment at being rejected knows no bounds.

In spite of the apparent bias, however, this ugly world is at the same time robust, vivid, and often comical to the extent that it is entertaining in the way pornography typically entertains. Moreover, even if the author refrains from using graphic detail to portray a sublime sexual union, he nevertheless conveys an extremity of rawness that all the same evokes what I would call a kind of reverse sublime. By reverse I mean in effect obverse, that is, the inherent other side of the chaste and rarefied sublime, an other side that is paradoxically true at the same time. We can also view the author's inclusion of this reverse sublime as a matter of choice. Why does he choose to write in such lurid detail of something he at the same time condemns? Or rather, we might ask, how can he do so without affirming what he goes to such trouble to negate? Could he in fact be doing two things at once and thereby be aiming at something in common, namely, a sort of radical pleasure, an uncanny and pulsating jouissance that defies containment and lies outside the homeostatic world of normal pleasure and pain? We might further say that one sort of sublime is out of reach above - that of the love between the mingshi and dan - and the other is menacingly pulsating below - that of the world of grotesque dissipators. Although the author explicitly favors the high sublime, my point is that he cannot adequately portray it without including its uncanny obverse. He may appear to favor one over the other in all sorts of ways, but he nevertheless cannot portray the complete truth of the vision of love between men without exploring 
every mode in which that love occurs. His passion in writing this book must therefore go all the way. In so doing, he entirely conforms with the thematics of radical passion as it has developed since the late Ming treatment of qing, from authors such as Tang Xianzu 湯顯 祖 and Feng Menglong 馮夢 龍 onward.

The grotesque obverse of the high sublime comes across in imagery comprising both features of physical appearance and descriptions of sexual activity. Throughout the book he portrays characters acting according to their level of “moral character" (renpin 人品). Simply being ugly is a sign of low renpin, where ugliness includes being nearsighted, dull-witted, or having a "flat face and smashed nose" (2.23). The lowest villain is a crass opium merchant from Canton, the region that is farthest from dignified Beijing. He is Xi Shiyi, darkskinned and of despotic temper (Chapter 3). When ugliness appears in the author's pornography, it is a case of a vagina with hair like a "beard stained with milk tea" (23.5ab) or like "lush thick grass" (39.15b); the sounds of a man and woman having sex are like "a dog slurping" (51.10a). ${ }^{40}$ A pseudoliteratus with "fox stink" (body odor, 40.498) speaks in malapropisms to describe the pleasures and techniques of anal sex. Use a wet piece of "wood mushroom" as a "cap" to keep the fecal smell off the penis, he advises (23.16a). Men who like anal sex are ones who "like to ride the wagon," that is, the "nightsoil wagon"; they "like to clean out the outhouse" (27.328). The merchant Pan Qiguan tricks a boy into sex by getting him drunk, then stuffing his anus with hair to make it itch and crave penetration (40.500-1, 8ab). Friends help the boy avenge himself by doing the same to Pan: one of them oils up his middle finger and stuffs Pan's anus with hair and a kind of chemical (yao 藥, 40.507-8), which then makes Pan go to ridiculous lengths to find someone willing to penetrate him and sooth the itch (Chapter 47$).{ }^{41}$ In the process Pan solicits an eighteen-year-old man, Tianxiang 天 香, a xianggong 相 公 (female impersonator and male prostitute) who has himself suffered this same affliction. Pan tells him that he has heard of men

40 For censored portions of the Guiguan and other editions, one must go to the edition in traditional binding, Gest Library, Princeton University (n.d.).

41 While I can find no other source to help clarify the nature of this practice, it is safe to assume that methods existed to aid in anal intercourse and to deal with the common side effects including injuries. The same situation existed in Japan, as Pflugfelder reports, where lubricants were available and in which so-called "stick medicines" were used which were coated with copper sulfate and inserted into the anus for the purpose of dilation (Cartographies of Desire, 238-39). 
who even in old age want someone to penetrate them because, he assumes, they have been tricked in this way when they were young (47.18b). But Tianxiang himself never gets an erection and has an especially small penis, as if he never became fully mature (47.17b). His experience, as he tells Pan, is that anal intercourse is only a pleasure (kuaituo 快 活) for the other, never for himself (47.18b). The height of dissipation takes place with Xi Shiyi, who contracts syphilis from Tianxiang and whose penis swells painfully until it looks like a "rotten eggplant" ( $40.7 \mathrm{~b})$. He loses part of his penis, then has an operation in which part of a dog's penis is grafted onto his (Chapter 47), but he finally ruins his organ permanently when he takes aphrodisiacs and has violent sex with his concubine and then with a boy whose anus is likewise grotesquely ruined and who dies a year later (Chapter 58).

We cannot make the mistake of concluding that because of such relentlessly demeaning imagery the author must be a sincere loather of sex. On the contrary, the extreme vividness of his portrayal of the obverse of the high sublime ultimately gets at the same thing: an uncannily magnificent other side which also drives the passion of love between men. Similarly, this other side does not represent a realm that can be captured and taken as a comfortable abode. For people like Xi Shiyi, passion leads to self-destruction. For people like Ziyu and Qinyan, passion is always missed and out of reach. In their case, in her former life Qinyan was a woman who died young. The suggestion is that they have missed each other by a lifetime, for Ziyu cannot marry Qinyan now. But the point should also be that an author like Chen Sen loves it that things would be this way, that is, missed or off by a lifetime, no matter if Qinyan and Ziyu were man and woman in the same lifetime. In other words, Chen Sen tries to portray a passion that is more profound and unapproachable than one finds in conventional tales of love matches, both chaste and erotic. Like Cao Xueqin, in fact, he is utterly uncompromising when compared to other authors of love tales. He will never allow the sublime love he portrays to be domesticated and cloaked in untroublesome attire.

Between Chastity and Dissipation

We are met at this point with a question that begs for a brief digression. Might there exist a realm that lies somewhere between callous dissipation and rarefied chastity? In several remarkable passages, Chen 
Sen does in fact suggest in a tantalizing way the off-stage existence of a third realm besides these two extremes. It is as if he tries to indicate a male same-sex love of a more everyday variety, that is, a nonmercenary and relatively status-free love that includes sexual attachments.

The main vehicle for portraying this type of love is the hint in passing, which takes the form of the knowing look or the telling detail. The author puts the reader in the position of reading between the lines, although the author does not make it difficult to do so. The effect of this suggestiveness is to make a statement in line with the one asserting that if the young scholar truly loves the dan, then the dan should no longer have to be a dan. Roles like that of the dan (including that of the male prostitute, who usually appears in the form of male hairdresser and masseur) represent forced externalities that should not, as the novel implies, interfere with the passion between mutual lovers.

Two male characters appear to be engaged in an affair, Hua Guangsu 華光宿 and Feng Zipei 馮子佩. The relationship somewhat resembles that between a patron and a dan except for the fact that Feng, the dan-like character, is not a dan and is adamant in making it known that he does not like being compared with one. Feng is rather like a free retainer of the wealthy opera connoisseur Hua, who himself owns his own acting troupe and has dan and former dan living under contract in his household for the purpose of both counsel and entertainment. The relationship between Hua and Feng is extremely discreet, however. The first notice, which only makes sense when re-read after later passages, is the mere detail in Chapter 6 that Feng arrives late at a gathering, having been at Hua's. At this point, Feng is said to be very wumei 嫹媚, that is, "charming like a woman" (6.80). When we learn more about him in a later chapter, he turns out to be the son of a deceased official and to be relying on friends to get by after having wasted his family money (Chapter 19). He is again described as a man of fragile feminine beauty. When two guests arrive, he emerges "daintily and charmingly" wearing an entire outfit of delicate gauze (niaonuo duozi 婂 娜多姿, 19.236). One guest "hugs him tightly," then they all three hug each other around the waist. One of them sniffs Feng's face and remarks that Feng is more like a boy than a young gentleman. Then, before sitting down and talking, the three of them "play and tussle for a bit," sihun yizhen 廝 混一陣 (236). ${ }^{42}$

\footnotetext{
42 For other uses of the word hun in this sense, see the late Qing Haishanghua
} 
This is the only passage in the book in which men of more or less equal status interact in such a way, and then proceed with their socializing. But it is crucially significant as a sort of whispering of the existence of this other dimension of male homoeroticism which is less tied to the masks of status than the relations between patron and dan. These suggestions continue in the form of a series of traces only, never anything direct. Later, Hua's wife is said to sense that Hua and Feng "might be up to something," but she is never jealous or interfering (xingï keyi 形跡可疑 literally translates as “their appearances aroused suspicion," 26.319).

Another scene of suggestiveness occurs when Feng performs Kun opera for Hua and others. When Feng suddenly arrives, Hua "is distracted for a moment" (lengle yileng 愣了一愣 30.372). Watching Feng sing, Hua is “mesmerized" (chushen 出 神, 30.375), while everyone watching is surprised at how beautiful and woman-like Feng is. At the same time, Feng notices everyone's regard, which makes him blush, but he insists on one thing: he will not be regarded as a xianggong (373). Later, at a gathering of dan and their admirers, he stays apart and makes a flower wreath to give to Hua, who smells it appreciatively before handing it back to him (31.380). On other occasions as well, Feng distinguishes himself from xianggong, with whom he does not like to be compared or to associate. Lying down with Wei Pincai 魏聘才 (with whom he had “played and tussled” in Chapter 19), they discuss $\mathrm{Xu}$ and Hua, whom they say both look too highly upon xianggong (Chapter 34).

What all these scenes have in common, besides their hidden eroticism, is the dechanneling of male love from the framework of roles as played in the mingshi/dan or client/prostitute couples. Feng, his friend Wei, and Hua are all of lower renpin than Qinyan, Ziyu, and others, but they are nevertheless vehicles for the same message the author delivers elsewhere via the sublime lovers. What these characters of lower renpin suggest is the possibility of sexual involvement between men who are mutually attracted but not involved in a relationship of mutual exploitation, as in the case of the conniving male

liezhuan 海上花列㑕, where a variant of this phrase occurs when a prostitute and her client “fool and tussle for a bit," guihun yizhen 鬼混一訷, Han Bangqing 韓护 慶, Haishanghua liezhuan (Hainan: Hainan chubanshe, 1997), 6.43. See also Dream of the Red Chamber in which Baoyu says he once "fooled around" hunle 混了 with You Sanjie 无二耻; Cao Xueqin, Honglou meng bashi hui j̈aoben 紅慺夢八十四校本 (Hong Kong: Zhonghua shuju, 1985), 66.741. 
prostitute and his rich and lustful client. If Feng Zipei fails, it is because he unfortunately lacks a zhiji. It is as if he emerges into the male homoerotic scene of Beijing expecting that he can do so without being subjected to the risks that the usual xianggong must face. He tries to avoid being designated as a xianggong because he knows well that xianggong automatically risk being subjugated and harassed. He is nevertheless still regarded as one and suffers because of it (he was once raped by Xi Shiyi). Hua Guangsu, moreover, will never love him as Xu Ziyun loves Baozhu or as Ziyu loves Qinyan. ${ }^{43}$

\section{Part III The Status of Femininity}

"We Are All Dan"

With the significance of chaste and vulgar now better defined, let us return to the question of the status of femininity in Precious Mirror, first in terms of the young scholar and the boy actor, then in the next section in terms of the women in the novel and their relations with men. The exchangeability of positions between the scholars and actors is of chief importance. As I have been indicating, the more valuable direction of exchange is becoming feminine or subjectifying oneself in the direction of femininity. The scholar looks like the dan, and the dan looks like the scholar. In spite of the prominence of the dan's femininity, it is in fact comparably significant that the scholar be cast as "crossable." The reason for this in the scholar's particular case is that being feminine is more conducive to realizing the subjectivity of the other person (whether one's lover or friend) than being masculine. In the dominant social order, masculinity is by rule the universal standard, the absolute position from which all else is perceived and directed (but perceived in a way that excludes the sense of empathy). By rule the masculine instrumentalizes - in the crudest terms, penetrates the feminine. The only way out of this onesidedness

\footnotetext{
43 At this point I would add that the slight and unheralded suggestion of a physical love somewhere between rarefied and vulgar love is on the same level as the numerous sexual innuendos that can be found throughout the text, including euphemistic jokes about the penis (7.86), catamites (longyang 能陽, 7.94), or anal sex (12.150). These instances occur during gatherings of mingshi, not just among the vulgar crowd (where such jokes are of course common as well, e.g., 8.101, 103). For that matter, women and especially their maids are portrayed engaging in sexual innuendo (11.141-
} $42)$. 
is for the young scholar to know the dan from the inside, that is, to arrive there subjectively. The understanding scholar's motto should thus be: "We are all dan."

This series of statements can be unraveled by examining the implications of the notion of zhïi as portrayed in Precious Mirror. The true zhïi, knower-of-the-self, is one who knows and listens to the other as if the other were oneself. ${ }^{44}$ The dan who is zhiji of the scholar reads the scholar's heart and recognizes the scholar's true talents. Thus the dan Huifang loves the scholar Chunhang who has fallen into poverty and misery, but whom Huifang then helps recover. As for the true knower of the dan, he must be able to understand the dan, where the identifying word for "understand" is titie 體 貼, which also means to sympathize, empathize with, and be considerate of. As the dan Baozhu says, a person like Hua Guangsu has no capacity to titie. Someone like Xu Ziyu, on the other hand, does (33.403). ${ }^{45}$ The best illustration of the meaning of titie is the case of Qinyan, who tries the patience of Hua Guangsu because Hua cannot understand or tolerate Qinyan's constant moodiness. Xu, however, knows what that moodiness is about: it is the sign of both Qinyan's unfulfilled love for Ziyu and Qinyan's hatred of being a dan.

Equality and exchangeability between the mingsh $i$ and dan are evoked numerous times in the book via scenes or statements in which the identities of the two young men are overtly mingled and blurred. The focus on the transcendence of imbalance in this or analogous relationships is of course not specific to Precious Mirror, but is found in numerous earlier texts, Dream of the Red Chamber in particular, and in situations among real historical people. ${ }^{46}$ The famous affair between the early Qing literatus Chen Weisong and the actor Yunlang is one of the best examples. Volpp writes of the literatus's affectation of "ignorance of the gulf in social status" and refers to the exaltation of love like that between Chen Weisong and Yunlang as a

44 For a discussion of the history of zhiyin 知音, a variant of zhïi, see Paola Zamperini, "Lost Bodies: Images and Representations of Prostitution in Late Qing Fiction" (Ph.D. diss., University of California at Berkeley, 1999, Ch. 2). Volpp discusses zhiyin in terms of its "reach[ing] across boundaries of status" ("The Male Queen," 170-72).

45 The word baorong 包容 is also used with this sense (53.672).

${ }^{46}$ For "romantic egalitarianism" in the context of male same-sex love in Edo Japan, see Pflugfelder, Cartographies of Desire, 37-38, 82. For an excellent discussion of the dissolution of social and ritual boundaries in Dream of the Red Chamber, see Epstein, "Reflections of Desire," 90-95. On "egalitarian mutuality" in Precious Mirror, see Starr, "Shifting Boundaries," 284. 
love that was "unfettered by social hierarchies." 47 The crucial point in the relationship between zhigi lovers in Precious Mirror is that the repeated blurring of the images or identities always occurs in the direction of femininity - that is, away from the standpoint of the universal male subject. In any resemblance between two people, then, it is looking like the dan or the woman that is better than looking like the masculine other. In general, to be feminine or to look like a beauty (jiaren) is a mark of superiority and thus also a condemnation of the world as ruled by vulgar males.

The crossing between mingshi and dan occurs through explicit references to resemblances between the two and through situations in which socially prescribed roles are relaxed or reversed. Hua Guangsu is said to be as good-looking as a dan (5.65). Later, in the dan Qinyan's eyes, Hua looks like Mei Ziyu, that is, Qinyan's own lover (25.311). Ziyu in turn looks like the dan Lu Sulan 陸素蘭, as noticed at least twice $(10.122 ; 15.189)$. In all these likenesses, the masculine pole is never the better standard. In the case of the relaxation of hierarchical roles, the gatherings in Xu Ziyun's garden are exemplary. Xu insists that the dan be informal with him and other mingshi. The dan may visit whenever they like (5.61). The dan need not greet their superiors formally; and everyone will address each other by their literary style names (9.118). When Ziyu first meets Qinyan, Ziyu unconsciously confuses the sitting positions of host and guest (10.129). At a gathering at $\mathrm{Xu}$ 's, the dan occupy higher sitting positions than their superiors (37.459). In the novel's most famous role reversal, when Tian Chunhang first meets the dan Su Huifang, Su's horse carriage splashes mud on Tian, whose anger melts into adulating deference when he sees the beautiful Su inside the carriage (12.153). When Su later helps Tian, who has become poor from his own wastefulness, they thus reverse the usual situation in which it is the elite scholar who is the benefactor of the dan (but they resemble the common story of the courtesan who takes her savings to help her poor lover establish himself and redeem her).

So far my examples have relied on the cross between social unequals. But what about situations among those who are status-equals to begin with? In an outstanding though very brief example of elite male femininity, when other elite guests arrive, Shi Nanxiang 史南湘 greets

47 See Volpp, "The Male Queen," 118, 128. She also states that the literati's "pretense to blindness amplifies [their] passion, making it seem as though it knows no social stricture" (118). 
them wearing his wife's padded jacket because, he says, he just awoke and had no time to put on proper clothes (15.187). ${ }^{48}$ As casual and well-excused as this act may seem, it is another of the many minor suggestions which contribute to the general picture of the status of femininity. What is important to realize is that 1) the assumption of feminine attributes, 2) the resemblance to a dan or a jaren, or 3) the relaxation of social ordering, are not expressions of belief in essential and concrete feminine qualities, nor in some magical effect of putting on or acting out specific or concrete feminine roles. Again, femininity is a position to arrive at subjectively, not by deliberate means such as clothing, makeup, or express role-playing. Shi Nanxiang wearing his wife's clothing is more sublimely feminine than a dan dressing as a woman, in other words. That is, Shi's act is a better example of subjectively assuming feminine status than the dan's dressing in female costume. The reason for this is that the dan's act is performed contractually in the service of others, namely, the master of his opera troupe and then his audience and admirers. But as Qinyan emphasizes repeatedly, he does not want audiences and admirers. He does not want to be desired by these people, whom he loathes as soon as they desire him. Qinyan as woman does not want to exist because such an existence is a priori for someone else, namely, the male patron.

In sum, for the scholar to titie the dan or to be the dan's zhiji is to understand the dan's predicament, especially as that predicament is enunciated by Qinyan. When the young elite male acts in a way that is tantamount to saying "we are all dan," he joins with the dan in an implied questioning of the normative assigning of roles with which these subjects find themselves radically at odds. The dan is as if asking: Why do you want me to be this way? What is it in me that you see? Both mingshi and mingdan are thrown into this persistent questioning, which sends them into depression and illness, especially in the cases of Qinyan and Ziyu. Insofar as they are trapped in this miserable situation, they lead a fractured existence, which causes them constantly to weep, to fall ill, and to be listless and spiritually absent when others desperately desire to see them so much as smile.

48 Shi's name, Nanxiang 南淋, puns with nanxiang 男向, which can be translated as "affinity for men." 
Women in Precious Mirror

Superior women

There remains, however, the problem of the status of women in Precious Mirror, about which two separate things can be said. First, the women occupy another realm much as if they are abstract superior beings, something like immortals in contrast to the male lesser beings, whether scholar or dan. At the same time, they also appear in a completely different light in which, as Starr notes, they constitute a masculine presence ${ }^{49}$ In this light, the scholar and actor are more feminine than women, which means in effect that the women are portrayed as subscribing to the masculine order more thoroughly than the young men.

In a novel written by a man in which men appropriate women's roles, the question of the "realness" or credibility of the female characters is, of course, highly problematic. The characterization of women in Precious Mirror is often little more than a caricaturization. The emphasis on male appropriation of female roles clearly puts a severe limit upon the status and agency of women in the novel. Nevertheless, the treatment of the ideal of femininity potentially subverts the conventions of women's subjectivity as much as that treatment subverts the conventions of mingshi or dan subjectivity. How successfully Precious Mirror is in carrying out its subversions is another question to be left for my conclusion. ${ }^{50}$

Let us look at the two opposing aspects just mentioned-women as beings apart and women as purveyors of the masculine, symbolic order. The image of women as beings apart is an example of the theme of the superiority of women, which is virtually an accepted truth in the moral and aesthetic universe of Precious Mirror. Superiority in this instance is of course a belief or construct that carries with it assumptions that do not necessarily or automatically privilege women in social and economic terms. The prior source that lends the most weight to the idea that women are like immortals or beings of extreme purity is Dream of the Red Chamber, but many other works before that contribute as well, including late Ming literature idealizing the heroic courtesan, Pu Songling's Liaozhai zhiyi, and the many beauty-

49 Starr, "Shifting Boundaries," 298-300.

${ }^{50}$ Male control of the fictional portrayal of women is a recurrent topic in Zamperini's recent dissertation ("Lost Bodies"). I have been inspired by her work in my considerations here. 
scholar dramas and romances of the Ming and Qing. Jia Baoyu's contrast between muddy, impure men and pure (like water) women (imagery that is also recalled in Precious Mirror, 1.9), his love of virgin's lip rouge and used face-washing water, and his detestation of things touched by older maids are some of the famous examples of this theme. When Hua Guangsu in Precious Mirror demands that a certain delicious concoction be prepared by the young maids and not the dirty older women, he echoes the fancies of Jia Baoyu in what by Chen Sen's time is already a classic allusion (26.315).

In other instances, both married and unmarried women have parties during some of which they engage in an activity that is emblematic for all "talented women," cainü, in the Ming and Qing: they compose poetry together. ${ }^{51}$ Two of these occasions nearly take up whole chapters of their own. ${ }^{52}$ As beauties and as poets they are like the jaren (beauties) of the beauty-scholar romances or the talented women who live in the garden in Dream of the Red Chamber. They are special both because of their supreme talent and because of their purity, whether they are virgins or married. The married women are notably beautiful, including two in their late thirties and early forties, as specifically remarked at least twice $(6.69 ; 52.664-65)$. A number of wives and their husbands, the elite young heroes of the novel, are said to love each other like the ideal beauty-scholar couple.

At the same time, as studious as the novel is in creating an image of remarkable women, they ultimately and necessarily must pale next to the passionate main focus of the novel, the men who are the dan and their patrons. Accordingly, the women appear as if fixed and bracketed in their station of talented beauties. They have parties, write poetry which one of their husbands then publishes $(\mathrm{Xu}$, Chapter 12) or another of them adores (Hua, Chapter 41), and demonstrate their tremendous talent (Qionghua 寶華, Ziyu's wife-to-be, has a phenomenal memory and delivers an eloquent discourse to other women on poetry, Chapter 54). But in fact the married womens'

${ }^{51}$ See Ko, Teachers of the Inner Chambers; various essays in Widmer and Chang, eds., Writing Women in Late Imperial China; and Susan Mann, Precious Records: Women in China's Long Eighteenth Century (Stanford: Stanford University Press, 1997). Without these and other similar studies, I would not have recognized the importance of this feature in Precious Mirror.

52 See Chapters 11 and 57, but also see Chapters 6, 41, and 52; in Chapter 41 Hua Guangsu watches and listens as his wife and maids perform. 
husbands spend too much of their time with male friends and especially enjoy the company of dan. When Hua Guangsu's wife suggests that he take one of their maids as concubine, he refuses. When he says that she looks like one of the famous dan, she is unhappy (26.318). $\mathrm{Xu}$ 's wife composes lyrics containing complaints about her husband for staying out late at night in his garden, where he has gatherings with dan (11.138). At one point, Xu's wife challenges him by asking what is the good of dan (11.133). At a party held by Xu's wife, the women swear sisterhood and promote the idea that Qionghua's excellence in poetry makes a case for the merit of women over dan (57.741). These are all instances that demonstrate rivalry between women and dan, although to be sure they amount to minor registrations of dissatisfaction which pose nothing like the classic fury of the jealous wife.

Women as Masculine Presence

What begins to appear as we see these hints of rivalry is the second aspect of the remarkable woman that I mentioned above, her masculine presence. In short, when women resemble the dan, they do so in the mode of the theme of superior women. When the women rival and complain about the dan, they cross into a mode in which they constitute a masculine presence. The best illustration of this second aspect can be seen if we draw some comparisons between Precious Mirror and Dream of the Red Chamber, in doing which we should propose the following equations. ${ }^{53}$ Mei Ziyu corresponds to Jia Baoyu, Ziyu's wife Qionghua to Baochai 寶鈫, and Qinyan to Lin Daiyu 林黛玉. ${ }^{54}$ Both Ziyu and Baoyu, who of course share the jade character in their names, are beautiful young men who are childlike in purity (Ziyu is explicitly compared to a "virgin," 15.188), who are unlecherous, and who both fall into illness and delirium when blocked

\footnotetext{
${ }^{53}$ Wang takes Precious Mirror as a kind of sequel to Dream of the Red Chamber: "Because of its tremendous popularity, Hongloumeng was rewritten into a homosexual romance (Pinhua baojian ...) ..." (Fin-de-siècle Splendor, 29). Also, Chen Sen "apparently meant the novel to be read like The Story of the Stone" (39). For some of Precious Mirror's borrowings from Dream of the Red Chamber, see Wang, 64. The author of a recent work on Dream of the Red Chamber sequels likewise regards Precious Mirror as a kind of sequel or imitation. See Zhao Jianzhong 趙建忠, Honglou meng xushu yanjüu

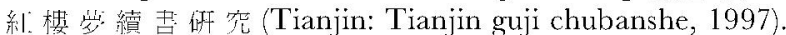

54 Regarding Ziyu and Qinyan, Wang says: "As for Du Qinyan and Mei Ziyu, who can better serve as their models than Lin Daiyu and Jia Baoyu...?" (Fin-desiècle Splendor, 63).
} 
in their attempts to realize their love. ${ }^{55}$ Qionghua and Baochai, the wives decided upon by the elders, are both highly literate and vigorously intelligent. ${ }^{56}$ Baochai constitutes a presence which calls Baoyu to the serious task of being a father and preparing himself to take the examinations in order to become an official. ${ }^{57}$ Similarly, Qionghua calmly waits for and expects Ziyu to join her in marriage and the other serious tasks of joining the world of grown-up mingshi. Although she is aware of Ziyu's relationship with Qinyan, and sees through Ziyu when he prevaricates about the affair, she never displays jealousy or anger. ${ }^{58}$

The resemblance between Daiyu and Qinyan lies in their role as the sublime zhiig lover. But the love for Daiyu or Qinyan is an impossible and even subversive one because it threatens to undermine the relationship determined by the elders. Daiyu and Qinyan, moreover, are moody types who refuse to listen to the call to play their roles properly. The endings of the two novels vary in that Daiyu dies of melancholy, while Qinyan courageously kills his dan self and turns into a young scholar, that is, a full-fledged self. Daiyu's death, nevertheless, constitutes a condemnation of her marginalization in life (and of the untruth of the match between Baoyu and Baochai), just as Qinyan's symbolic death condemns his existence as dan. Baoyu and Baochai marry, as do Ziyu and Qionghua. But Ziyu manages to keep his friendship with Qinyan, as does Chunhang with Huifang after Chunhang's marriage. The suggestion is that Ziyu and Chunhang have realized their loves as ideally as possible since they continue open friendships with their former dan lovers even into their marriages. Meanwhile, Qinyan and Huifang will presumably marry and themselves have families (as the novel implies).

Now to summarize the way in which the "talented women" in the book constitute a masculine presence. Any time the woman is like Baochai and, so to speak, tells the man to be a man, she taps into the authority of orthodox masculine discourse ${ }^{59}$ When Hua Guangsu's

55 Ziyu's delirium is the focus of Lu Xun's well-known discussion of the novel, A Brief History of Chinese Fiction, 319-22.

56 Starr notes the idealization of masculine intelligence in women like Qionghua ("Shifting Boundaries," 298, 299).

${ }^{57}$ See Yu's discussion of Baochai in this regard, Rereading the Stone, 186-88.

${ }^{58}$ Further, when Qinyan finally returns to Beijing safely after harrowing experiences in the south, Qionghua expects that Ziyu will no longer be talking in his sleep, as she says to him (59.766-67; Ziyu had been longing for Qinyan who was far away in Nanjing).

${ }^{59} \mathrm{Or}$, according to $\mathrm{Yu}$, we could posit "two kinds of 'the feminine': one that 
wife offers him a concubine, she in effect tells him that he is supposed to love women, not other men. To put it simply, she represents the male-dominated social order when she urges him to be like a serious, conventional man. Likewise, as accommodating as Qionghua is, she still prods Ziyu into confessing his secrets and, when Qinyan finally becomes a full-fledged young scholar, she lets Ziyu know that it is time to stop acting like a childish star-crossed lover.

Another question still remains, however, that has to do with the resemblances between wives and dan. What, in short, is to be made of the resemblance in looks between Qinyan and Qionghua and between Huifang and Chunhang's wife (the latter two even share the same surname)? In answering this question, I want to avoid one conclusion in particular, that the wholesome ending of the novel would make what precedes it seem nothing more than a temporary diversion. As Starr says, the dan are nothing more than "temporary females," and patron and dan are merely "temporary homosexuals," all of whom are "required to grow up and straighten out." however, is that if we take this wholesome ending too seriously, we violate a cardinal rule of Chinese fiction, namely, that a normative ending should not be seen as canceling out the wayward body of the story. If we follow this rule, then we must believe that the so-called temporary aspects of the story are where the story's main message lies about arriving at feminine subjectivity.

The tension between adherence to the rules of the orthodox family and the pursuit of same-sex love is something that Precious Mirror in fact presents as impossible to resolve, hence the ambiguities raised by the resemblance and rivalry between wives and dan. The difference between wife and dan is like the gap that exists between real and sublime. Precious Mirror visits this gap repeatedly as it alternately and even contradictorily stages marital conclusion but also sublime (that is, unrealizable) love. A prime instance of the staging of this gap comes across via the logic of karma as spelled out at the end of the novel. Qinyan was in fact a woman in his former life and as such was the perfect match for Ziyu. But they have missed each other by

openly subscribes to the norms of the Confucian discourse and an emergent one that reflects a more resistant and skeptical attitude" (Rereading the Stone, 246).

${ }^{60}$ Starr, "Shifting Boundaries," 301. The use of the word homosexual needs to be qualified in that such a concept of identity did not pertain in the milieu of Precious Mirror, as Starr herself notes ("Shifting Boundaries," 272). Pflugfelder provides a relevant discussion of the inappropriateness of the term homosexual in the context of Edo-period Japan (Cartographies of Desire, Ch. 1). 
a lifetime. The depth of their love is hard to explain otherwise, as marveled onlookers conclude; something else, namely their karmic bond, must lie behind their love (53.671). Still, regardless of otherworldly destiny, in this life they must unquestioningly obey the call of social norms.

The expectations of this calling are explicitly laid out in the form of two dreams, one Ziyu's, the other Qinyan's. In Ziyu's dream, Qinyan sits seductively in Ziyu's lap, then suddenly turns into a woman inviting him to her chambers, and tells him: "Heaven's rule and earth's reason dictate that love should be between man and woman."61 Qinyan's dream follows the same lines. Qinyan sees Ziyu being intimate with a woman who looks like himself in opera dress and makeup. ${ }^{62}$ When the woman discovers Qinyan spying on them, she throws a mirror at him in which he sees himself as the woman he was in his former existence. When he again looks into the mirror, he sees mingshi and mingdan on the proper (zheng 正) side, and villainous characters on the obverse (such as Wei Pincai and Xi Shiyi, 56.716-18). These two dreams focus sharply on the issue of Ziyu's split loyalties, but nevertheless resolve the problem in the direction of the order of male and female principles which, having the last word, determine the earthly reality of marriage. At the same time, the final message that the mirror delivers in turn reinforces the ideal of sublime love between mingshi and mingdan.

Yet another way to address the ambiguities raised by the resemblances between wives - the so-called "real" women-and dan is to keep in mind that Precious Mirror pretends to be more than a dramatization of "will the lovers get together or not." The ending in which the dan gloriously burn their opera paraphernalia prevents the reader from focusing entirely on who marries whom, a question which by implication is thus an ultimately tangential not culminating one. Such an ending avoids letting the reader conclude that the story is simply about failed love in the way that Dream of the Red Chamber was (which spawned numerous sequels trying to repair the damage). The salva-

${ }^{61}$ She then chides him for stubbornly sticking to Qinyan. Recalling Daiyu in Dream of the Red Chamber, Qinyan reappears emaciated from grief and angry at Ziyu for betraying him. Finally, Ziyu's father appears and yells at Ziyu for secretly leaving home to have this tryst (53.677-79).

62 Before this, Qinyan sees a goddess angry at a boy as a nearby attendant pours pens into the boy's pouch. Qinyan's mentor and adopted father, who also appears in the dream, interprets this to refer to the fact that in the future the boy will become a famous writer. See 55.716-17. 
tionist note should instead lead us into a concluding re-consideration Qinyan's "leaving his profession." I propose that we do so in light of Precious Mirror's historical inheritance of the Ming and Qing ideology of qing as embodied in the trope of the heroic woman, often known as the nüxia 女 俠, "chivalric woman."

\section{Part IV "Leaving the Profession"}

The Salvation of Symbolic Death

The nüxia is one of the most central figures in literary treatments of qing ideology. As Vitiello writes, the term nüxia "quite consistently involves a more or less literal degree of gender-crossing," as seen in her intellectual parity with men, her acts of cross-dressing, and in the traits that Li Wai-yee has also summed up, such as chivalry, loyalty, courage, resoluteness, and independence of spirit. ${ }^{63}$ The relationship she has with the male, moreover, models itself on the relationship of zhiji, the traditional ideal of male friendship. This joining of nüxia and zhiji leads Vitiello to conclude that in the late Ming romantic ideology, "friendship between two men becomes the paradigmatic model of romantic love," a model that he finds applies in both homoerotic and heteroerotic contexts. ${ }^{64}$ This model is most frequently illustrated in beauty-scholar romances which use the figuration of symmetry between male and female lovers to portray a relationship that is like that between two (same-sex) literati friends. ${ }^{65}$

In Precious Mirror, such gender-crossing appears in both major and

63 See Vitiello, "Exemplary Sodomites," 217, and Li, "The Late Ming Courtesan," 61. On intellectual parity, see Li, 63. Li also reflects on heroines of drama and fiction who are "more passionate and interesting" than their male counterparts, 71-72.

64 Vitiello, "Exemplary Sodomites," 217, 237-43.

65 See McMahon, Misers, Shrews, and Polygamists, 99-103. A particularly forthright enunciation of this blurring of male and female appears in the Honglou meng sequel Honglou fumeng. When Baoyu (reborn as Mengyu 夢 干) consorts with his wives and maids, "he is not even aware that he is male and they are female. As far as he is concerned, someone else's body is mine, and mine is someone else's.... Even if one of the women is sponging herself or taking a bath, he comes and goes as he pleases and no one minds" 並不知道白身是男他人是众, 覺得他们身子就是我

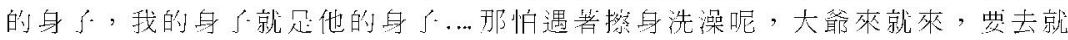
L., 㮥其舟然 (26.287). Chapter 13 contains the first major explication of his nature (13.139-40), including that the women "forget that he is a man" ye wangle Mengyu shi ge nanren 也忘了夢下是個男人. 
minor forms, the minor instances in particular showing how readily adaptable and codified these forms have become. Examples include a dan who himself dresses as a swordswoman, maids in Hua Guangsu's employ who dress in male clothing, and the dan Baozhu's comment about how "stupid" they, the dan, are compared to the women his age who compose such superior poetry (15.193). Major instances include Qionghua and her tremendous learning and the special gatherings of "talented women," cainii, a trope closely related to niixia. When the dan themselves remain aloof from the vulgar crowd, fight for their virginity, and ultimately liberate themselves, they are like the late Ming nüxia who is independent and resolute in her loyalty to her lover and to her own convictions, which include her steadfast support of the Ming dynasty during and after its downfall to the Manchus.

What, then, is Precious Mirror's self-proclaimed difference from its predecessors? Ziyu and Qinyan are said to be "better than all the scholars and beauties in the world" (22.280). They represent this model, in other words, but are supposedly more sublime. What qualifies them as "more" sublime is the dan's very likeness to a woman. He is not the same as a woman, who by inference, as I have been saying, is too concrete. This implication of concreteness certainly does not leave real women in a very viable position and in fact brackets them into a virtually neutered world, just as the novel confines the women within the few chapters in which they play happily among themselves as their husbands and husbands-to-be play more passionately elsewhere. ${ }^{66}$ Nevertheless, Precious Mirror makes a radical statement about the love fantasy in its dominant manifestation in which a masculine subject is in love with a feminine object. We must again realize the significance of Qinyan's gaihang and what it means in terms of the relationship between masculine and feminine subjects.

To begin with, Qinyan's gaihang should also translate as "I do not

66 As Starr says, the ending of Precious Mirror is a "neat conclusion for all but the women" ("Shifting Boundaries," 302). But see Zamperini's discussion of the prostitute-seamstress in Precious Mirror. This lower-class woman, although a very minor character, demonstrates considerable talent in her ability to size up and fleece her male customers (Ch. 51). In contrast, the higher-class males (albeit of low renpin) appear inept and foolish. See Paola Zamperini, "Clothes That Matter: Fashioning Modernity in Late Qing Novels," Fashion Theory 5.2 (2001): 1-20, and also her dissertation, "Lost Bodies," for a fuller discussion of agency and the prostitute in late Qing fiction. 
exist as your fantasy." Furthermore, his exit from the "dan corps" (dandang 旦黨, 60.769) is a symbolic death, and it is a symbolic death carried out from the position of a feminine subject. Even if he is not a real woman, and even if he has social privileges as a male that a female does not have, Qinyan revolts as a woman against the male order as that order is materialized in the male gesture of the idealization of the woman. Qinyan's act is a real one in that it escapes this idealization and in that he emerges into a truly different status, having negated the former one unconditionally. His action implies that it was an accident for him to become a famous dan and as such an object of fascination. There was nothing real in him that made him beautiful except as others desired to see it. To be sure, other dan (especially the vulgar xianggong hairdressers who dress as women) fully engage themselves in their roles in order as best as possible to gain their livelihood and fleece their obsessed male customers. These xianggong take up the lie of male fantasy with all certainty and selfapplication and thus in their own way realize and take advantage of the illusionary aspects of the fantasy formation. Qinyan, on the other hand, never ceases to question his role and finally succeeds in effect in killing his dan self and creating himself anew.

The Ethics of Equality

But besides what we may call the symbolic level of meaning, there is also an ethical message in Chen Sen's portrayal of sublime passion. This message has to do with the enslaving mistreatment of dan and how that mistreatment is never outside the picture of the otherwise exquisite aesthetic of Kun opera. As I have been saying, rigid alignment according to features of status and gender is the fundamental reason for the impossibility of the dan's existence. This impossibility achieves perfect visibility under what circumstances? When the patron falls in love with the dan. When the patron becomes the zhiji of the dan, the dan can no longer be a dan. The patron cannot love a slave without liberating him, in which case the two must gain equal status.

But where do they go from there, and what is the significance of an affair that in the end has to be superseded by marriage? For once the dan are liberated, the heroes enter normally adjusted married lives with women who, it turns out, look like their male lovers and who meanwhile do not object to their husbands retaining their friendships with their former lovers. The ending of the novel thus bows to 
the norms of male-female marriage, but simultaneously indicates the existence of a sublime love that still exists somewhere else. The author, moreover, resorts to a traditional method of indicating this elsewhere by inscribing it in textual form. Just before Qinyan, now a literatus, leaves for the south to live with his adopted father, he and Ziyu exchange parting poems, with Qinyan's being inscribed on a fan for Ziyu (Chapter 48). The fan later ends up in the hands of Hua Guangsu, whose wife chances upon it and wonders at the poem (52.662-63). It resembles none of the usual parting poems: those between friends, between husband and wife, or between prostitute and lover. Hua Guangsu affirms her perception and explains who the lovers are. Hua covets the fan because of the extremely moving contents of the poem. Like many others, he is in awe of the love between Qinyan and Ziyu. Later, when Ziyu's wife Qionghua discovers the poems, she is likewise deeply moved by such extraordinary love (54.691). Instead of jealousy, she feels pleasure in the knowledge of the existence of such a rare form of love ${ }^{67}$

The final message of Precious Mirror is that this love is something that can only almost be. The ambiguity of such an ending lies in the question of whether such impermanence is due to the obligation to marry or to the missed quality of love in no matter what form. Precious Mirror in fact overlaps between both alternatives. It repeatedly stages a love story which is impossible to stage by, at the beginning of the novel, for example, simply noting a marvelous fragrance from a nearby carriage or describing the glimpse of a face as the carriage passes on (1.13), or by, at the end of the novel, portraying a poem that moves those who read it. None of these messages erases the specific quality of male-to-male love, which is the central theme of Precious Mirror and of the poems which are striking because of their failure to conform to normal readerly expectations. But the same messages have implications which extend to love in any context. For if, as Vitiello says, the homoerotic bond can be a paradigm of romantic love, then as this bond is played out in Precious Mirror, the suggestion is that sameness of gender is not the liberating factor. Instead, what is liberating is the challenge of the relationship between equals, that is,

67 When she tries to induce Ziyu into telling her the nature and the details of the affair, he will not divulge anything, and she stops pressing him, not wishing to embarrass him further (54.691-94). This is one of the clearest points where, as Starr emphasizes in her article, the real woman is merely an "extra" who is "to be deceived for her own good" ("Shifting Boundaries," 293). 
being able to realize the other as equal. Equality does not mean the same in the sense of release into unproblematic oneness. Instead, it is difficult and even impossible. In the relationship between Chunhang and Huifang and between Ziyu and Qinyan, each is as ready to sacrifice himself as the other, in true zhïi fashion. Each cries for and defers to the other in ways that suggest neither can ultimately be superior to or in fact to "possess" the other.

It is particularly in the figure of Qinyan that this sacrifice turns into the keenest ordeal. Both in rebellion against his lot of being a dan and in his loyalty to his one true lover, Qinyan enters a stage of living death. The image that best captures this state is his refusal to smile for anyone, where anyone includes not only people like Xi Shiyi, but also refined and respectful ones like Xu Ziyun or Hua Guangsu. Hua manages to have Qinyan installed as a dan retainer in his palatial household where, under Hua's benevolent but forced rule, Qinyan passes the days, listless and tearful, with no intention of ever performing well again. Rather than viewing this living death as a form of passive resignation, we should see it as an act of radical significance. His act is like a flash of transcendent truth which sews the novel together at this one point and which, furthermore, ties Precious Mirror to a long line of predecessors featuring similar scenarios. These predecessors include the literary works (drama, fiction, poetry, biography) from late Ming to late Qing which sustain the constellation of ideas centering on qing and zhiji and foregrounding the figures of the nüxia, the cainü, and the various cross-gendering declensions of male and female characterization.

Is Precious Mirror therefore a study in nostalgia, merely harking back to the noble ideals of former times? There is indeed something nostalgic and even ahistorical about the notion of equality between friends or lovers as this notion keeps reappearing in different literary contexts. But we should also assert that Precious Mirror, like Huayue hen, Ernü yingxiong zhuan, and Qinglou meng, revives and re-realizes something which otherwise risks oblivion, and which in fact is already flattened and reduced in other fictional works (early nineteenth-century sequels to Honglou meng, for example, and even Qinglou meng) which produced what by contrast amount to stereotyped versions of otherwise highly potent messages. In other words, instead of reproducing a sameness, Precious Mirror reopens a theme the purpose of which is precisely to represent an opening to radical action.

We are still left, however, with the historical question of what significance Precious Mirror's extravagant dramatization of qing has in 
the particular moment of the novel's production. I conclude with a brief speculation about the historical context which, however obfuscated, still lurks at the edges of Precious Mirror's fictional world. For is it not possible to see that the sustained focus upon the noble souls of the heroes and their sublime love has an extremely timely significance for the period in which the novel was written? The contrast between Xi Shiyi and these noble heroes is enough to enunciate what amounts to a highly charged, even if muted, political position on the part of Precious Mirror and other mid-century novels (Huayue hen and Emü yingxiong zhuan in particular) which elevate similarly superior characters. In short, the novel's employment of the qing romantic ideology is by way of framing an ethico-heroic stance which, although seemingly soft and sentimental in nature, nevertheless sustains a certain militant energy. It is not difficult to see the portrayal of such heroes in turn as implying a specifically Chinese high cultural stance. For this reason we can begin to understand Precious Mirror and other midcentury novels as part of an emergent formation that for the time being still drew inspiration from a similar formation in the late Ming and early Qing when Han identity was pitted against that of the Manchus and when the qing aesthetic was likewise central to the enunciation of that position. 